Bangladesh J. Plant Taxon. 20(2): 185-199, 2013 (December)

(C) 2013 Bangladesh Association of Plant Taxonomists

\title{
POLLEN MORPHOLOGY OF RHODODENDRON L. AND RELATED GENERA AND ITS TAXONOMIC SIGNIFICANCE
}

\author{
A.K.M. Golam SARWAR ${ }^{1}$ AND HideKi TAKAHASHI ${ }^{2}$ \\ Laboratory of Systematic Botany, Graduate School of Agriculture, \\ Hokkaido University, Japan.
}

Keywords: Pollen morphology; Rhododendron; Infrageneric classification;

Generic delimitation; Rhodoreae.

\begin{abstract}
Pollen grains of 40 taxa of Rhododendron L. and its closely related genera, Therorhodion L. and Menziesia Sm., were examined by means of light microscopy and scanning electron microscopy (SEM), or SEM alone. Pollen tetrads of $R$. japonicum, $R$. schlippenbachii, $R$. tsusiophyllum and $M$. pentandra were examined also with transmission electron microscopy. In all the genera studied, 3-colporate, oblate to suboblate pollen grains are arranged in tetrahedral tetrads. The apocolpial pollen wall is composed of the exine - well developed tectum, columellae, foot layer and endexine, and the intine. On the contrary, the septal exine is composed of fragmentary tectum, and the two foot layers of adjacent grains are sometimes connected by columellae and endexine. Among different infrageneric taxa only the subsect. Ledum (sect. \& subgen. Rhododendron) was characterized by small sized pollen tetrads, higher $2 \mathrm{f} / \mathrm{D}$ value and rugulate exine sculpture. The pollen morphological characteristics overlapped each other in all other taxa. Thus palynological features showed little usefulness in the infrageneric classification of Rhododendron, however, they gave additional support to the individual generic status of Menziesia and Tsusiophyllum, and the sister relationship between Rhododendron and Therorhodion.
\end{abstract}

\section{Introduction}

The genus Rhododendron L., one of the largest and diverse genera of Ericaceae (Ericoideae, Rhodoreae), comprises over 1000 species (Chamberlain et al., 1996). The centre of diversity of the genus is in the Himalaya, but Rhododendron sect. Vireya (Blume) Copel. f. is also diverse in Malesia (Sleumer, 1966). Since Linnaeus (1753) established Rhododendron, this large genus has posed systematic problems in terms of infrageneric circumscription and rank (for details see Kurashige et al., 2001). Rhododendron and closely related genera are included in the tribe Rhodoreae (Kron et al., 2002). The taxonomic history of the Rhodoreae is complex (Gillespie and Kron, 2010), but a brief introduction may help to illustrate the variations in generic composition of this group. According to Stevens (1971), tribe Rhodoreae comprises the genera Rhododendron, Therorhodion, Ledum, Tsusiophyllum and Menziesia. The genus Therorhodion was hypothesized as sister to Menziesia + Tsusiophyllum + Rhododendron (including Ledum) (Kron and Judd, 1990). In contrast, Chamberlain et al. (1996) recognized only 2 genera, namely Rhododendron and Menziesia. The recent classification of the Ericaceae (Kron et al., 2002) recognized four genera in this tribe, namely Diplarche, Menziesia, Rhododendron (including Ledum and Tsusiophyllum) and Therorhodion. Therorhodion is often placed in Rhododendron (Chamberlain et al., 1996; Kurashige et al., 2001; Goetsch et al., 2005); the cladistic analyses of molecular data

${ }^{1}$ Department of Crop Botany, Bangladesh Agricultural University, Mymensingh 2202, Bangladesh. E-mail: drsarwar@bau.edu.bd.

${ }^{1}$ The Hokkaido University Museum, N10 W8, Sapporo 060-0810, Japan. 
also support reduction of the genus Therorhodion to a subgenus within the genus Rhododendron (Kurashige et al., 2001; Gao et al., 2002a; Goetsch et al., 2005). Recently Craven (2011) has suggested the inclusion of Diplarche and Menziesia to Rhododendron, that will make the tribe Rhodoreae monogeneric.

Pollen morphology has been shown to be useful for taxonomic and phylogenetic analysis of some Ericaceous taxa (Kron et al., 2002; Sarwar, 2007). The pollen of Rhododendron has also been studied by many researchers for taxonomic purpose as well as a part of regional flora (Huang, 1972; Vasanthy and Pocock, 1987; Fuhsiung et al., 1995; Mao et al., 2000; Terzioğlu et al., 2001; Gao et al., 2002b, c; Wang et al., 2006; Zhang et al., 2009; Miyoshi et al., 2011). All these results showed that pollen tetrads of Rhododendron were diverse in size and exine sculpture; sometime sufficient to differentiate the sections (Gao et al., 2002b; Zhang et al., 2009), but insufficient to differentiate the subgenera (Gao et al., 2002c; Wang et al., 2006). Moreover, our knowledge of pollen morphology and ultrastructure is still very limited for such a large genus as Rhododendron. Therefore, the objectives of this study were to clarify the differences of the pollen grains among Rhododendron and closely related genera of the tribe Rhodoreae, and to study the systematic significance of the micromorphology of pollen grains for the genus Rhododendron.

\section{Materials and Methods}

Pollen morphology of a total of 40 taxa of Rhododendron and its closely related genera of the tribe Rhodoreae, Rhododendron (34 spp.), Therorhodion (2 spp.) and Menziesia (4 spp.), was examined by means of light microscopy (LM) and scanning electron microscopy (SEM), or SEM alone (Table 1). The pollen tetrads of R. japonicum, $R$. schlippenbachii, $R$. tsusiophyllum and $M$. pentandra were examined with transmission electron microscopy (TEM) to study the exine stratification of respective genera. Polliniferous materials used in this investigation were taken from the dried specimens from the herbaria C, GB, SAPS, SAPT and TUS. Abbreviation of the herbarium names except for SAPT (the Botanic Garden, Hokkaido University, Sapporo) are according to the Index Herbariorum (Holmgren et al., 1990).

Table 1. List of taxa used in this study along with their voucher specimens.

\begin{tabular}{|c|c|c|}
\hline No. & Taxa & Voucher specimens \\
\hline 1. & $\begin{array}{l}\text { Rhododendron albrechtii } \\
\text { Maxim. }\end{array}$ & Japan: Hokkaido, Inaho pass, 22.05.1983, Takahashi 3975 (SAPS) \\
\hline 2. & R. arborescens Torr. & $\begin{array}{l}\text { USA: no locality, (Herb. Arbor. Harvard Univ.) Fl. 28.06.1892. Unknown s.n. } \\
\text { (SAPS) }\end{array}$ \\
\hline 3. & R. aureum Gergi. & $\begin{array}{l}\text { Japan: Hokkaido, Mt. Daisetsu; Mt. Asahi-dake, 20.06.1982, Takahashi } 2512 \\
\text { (SAPS) }\end{array}$ \\
\hline 4. & R. brachycarpum D. Don & Japan: Honshu, Mt. Zao, 08.07.1983, Takahashi et al. 40 (SAPS) \\
\hline 5. & R. dauricum L. & $\begin{array}{l}\text { Japan: Hokkaido, Iburi-shicho, Hobetsu-cho, 11.05.2004, Kanayama et al. 04-9050 } \\
\text { (SAPS) }\end{array}$ \\
\hline 6. & $\begin{array}{l}\text { R. davidsonianum Rehd. \& } \\
\text { Wils. }\end{array}$ & Scotland: Royal Botanic Garden, Edinburg, noday, 05.1971, C9180 (GB) \\
\hline 7. & R. decorum Franch. & China: Prov. Sze-chuan, Teng-hsiang-ying, 20.05.1922, Smith 2016 (GB) \\
\hline 8. & R. degronianum Carr. & Japan: Nagano Pref., Mt. Kimpu-san, 22.06.1975, Iketani 1763 (TUS 129348) \\
\hline 9. & R. dilatatum Mig. & Japan: Yamanashi Pref., Minamitsuru-gun, 01.05.1983, Togashi s.n. (SAPT) \\
\hline 10. & $\begin{array}{l}\text { R. diversipilosum (Nakai) } \\
\text { Harma }\end{array}$ & Japan: Prov. Mutsu, Mt. Hakkoda, 30.06.1978, Takahashi 206 (SAPS) \\
\hline
\end{tabular}


Table 1 contd.

\begin{tabular}{|c|c|c|}
\hline No. & Taxa & Voucher specimens \\
\hline 11. & R. formosanum Hemsl. & Taiwan: Taichung Co., Gukan-Chinsan, 16.03.1985, Murata 17561 (TUS) \\
\hline 12. & $\begin{array}{l}\text { R. groenlandicum (Oeder) } \\
\text { Kron \& Judd }\end{array}$ & $\begin{array}{l}\text { Greenland: Godthabsfjord, Ilulailik, Igdlorssuit, 17.7.1976, Hansen \& Fredskild } \\
1007 \text { (SAPT) }\end{array}$ \\
\hline 13. & R. hidakanum Hara & Japan: Hokkaido, Hidaka, Syoya, 10.5.1977, Tateishi \& Togashi s.n. (TUS 66107) \\
\hline 14. & R. indicum Sw. & Japan: Tokyo, cult., no day.05.1882, Miyabe s.n. (SAPS) \\
\hline 15. & $\begin{array}{l}\text { R. japonicum (A. Gray) } \\
\text { Suring. }\end{array}$ & $\begin{array}{l}\text { Japan: Nagano Pref., bet. Shirakaba-ko and Mt. Tateshina-yama, 29.05.1983, } \\
\text { Takahashi } 3998 \text { (SAPS) }\end{array}$ \\
\hline 16. & R. kaempferi Planch. & $\begin{array}{l}\text { Japan: Miyagi Pref., Mts. Abukuma, Wariyama pass, 10.05. 1986, Iketsu et al. } 95 \\
\text { (SAPT) }\end{array}$ \\
\hline 17. & R. keiskei Miq. & $\begin{array}{l}\text { Japan: Kagoshima Pref., Yaku Is., Mt. Tachudake, 10.05.1984, Murata et al. } 17861 \\
\text { (TUS) }\end{array}$ \\
\hline 18. & $\begin{array}{l}\text { R. lapponicum (L.) } \\
\text { Wahlenb. }\end{array}$ & Canada: Manitoba, Churchill, 26.06.1984, Gillett 1835 (C) \\
\hline 19. & R. macrosepalum Maxim. & Japan: Shokoku Isl., Kagawa Pref., Kida-gun, 05.05.1982, Takahashi 1033 (SAPS) \\
\hline 20. & R. macrostemon Maxim. & Japan: Hondo, Yamamoto in Settsu, cult., 10.05.1953, Togasi 688 (SAPS) \\
\hline 21. & R. maddeni Hook. f. & $\begin{array}{l}\text { Bhutan: Thimphu-Nimchling-Tanalum Bridge-Bunakha-Chima Khothi, } \\
\text { 01.06.1967, Kanai et al. } 346 \text { ? (TUS 57346) }\end{array}$ \\
\hline 22. & $\begin{array}{l}\text { R. mucronulatum Turcz. } \\
\text { var. ciliatum Nakai }\end{array}$ & Korea: Keisho-Nando, 20.05.1039, Yokoyama 299 (SAPS) \\
\hline 23. & R. nudipes Nakai. & Japan: Shiga Pref., Mts. Hirasan, 06.05.1981, Murata 10910 (SAPT) \\
\hline 24. & R. parvifolium Adams. & Japan: Prov. Nemuro, Ochii-shi, 16.06.1934, Tatewaki 20940 (SAPS) \\
\hline 25. & $\begin{array}{l}\text { R. quinquefolium Bisset et } \\
\text { Moore }\end{array}$ & Japan: Rikuzen, Mt. Funagata, 06.05.1972, Ogura 1637 (TUS 68874) \\
\hline 26. & R. schlippenbachii Maxim. & $\begin{array}{l}\text { Japan: Hokkaido, Sapporo-shi, Hokkaido University campus, cult., 18.05.2004, } \\
\text { Sarwar \& Takahashi s.n. (SAPS) }\end{array}$ \\
\hline 27. & R. semibarbatum Maxim. & Japan: Kyushu, Mts. Sobo-kutamuki, 07.07.1979, Murata 7987 (TUS 57400) \\
\hline 28. & R. subarcticum Harmaja & Japan: Hokkaido, Mt. Taira-yama, 30.06.1982, Takahashi et al. 2643 (SAPS) \\
\hline 29. & R. trinerve Fr. & $\begin{array}{l}\text { Japan: Niigata, Iwafune-gun, Takanosu-yama, 10.07.1974, Togashi s.n. (TUS } \\
\text { 67214) }\end{array}$ \\
\hline 30. & R. tschonoskii Maxim. & Japan: Honshu, Mt. Zao, 08.07.1983, Takahashi et al. 33 (SAPS) \\
\hline 31. & R. tsusiophyllum Sugim. & Japan: Hakone, Mt. Koma, 31.07.1926, Sawada s.n. (C) \\
\hline & & $\begin{array}{l}\text { Japan: Sagami, Komagatake in Mt. Hakone, 10.08.1927, Asahina \& Hisauchi s.n. } \\
\text { (TUS 4578) }\end{array}$ \\
\hline 32. & $\begin{array}{l}\text { R. viscistylum Nakai var. } \\
\text { amakusaense Tak. ex Yam. }\end{array}$ & $\begin{array}{l}\text { Japan: Kumamoto Pref., Mt. Nokogiridake, 30.04.1978, Minamidani } 29613 \text { (TUS } \\
\text { 100748) }\end{array}$ \\
\hline 33. & R. wadanum Makino & Japan: Prov. Rikuzen, Sendai-shi, Aoba-yama, 29.04.1977, Takahashi 550 (SAPS) \\
\hline 34. & R. weyrichii Maxim & $\begin{array}{l}\text { Japan: Shikoku, Kagawa Pref., Goshikidai, 28.04.1973, Shimamura et al. s.n. } \\
\text { (SAPT) }\end{array}$ \\
\hline 35. & $\begin{array}{l}\text { Therhodion camtschaticum } \\
\text { (Pall.) Small }\end{array}$ & Japan: Hokkaido, Mt. Chiroro, 07.08.1985, Takahashi et al. 5836 (SAPS) \\
\hline 36. & $\begin{array}{l}\text { T. redowskianum (Maxim.) } \\
\text { Hutch. }\end{array}$ & Russia: South Sakhalin, Poronaysk, 15.7.1937, Yoshimura \& Hara s.n. (SAPS) \\
\hline 37. & $\begin{array}{l}\text { Menziesia cilicalyx (Miq.) } \\
\text { Maxim. }\end{array}$ & Japan: Shiga Pref., Mt. Anzouyama, 03.05.1988, Tateishi \& Hoshi 13689 (TUS) \\
\hline 38. & M. goyozanensis Kikuchi & Japan: Iwate Pref., Mt. Goyozan, Tatamiishi-top, 07.07.1984, Mieno 445 (TUS) \\
\hline 39. & M. multifora Maxim. & $\begin{array}{l}\text { Japan: Prov. Rikuzen, Miyagi-gun, Izumigatake, 14.06.1978, Takahashi } 767 \\
\text { (SAPS) }\end{array}$ \\
\hline 40. & M. pentandra Maxim. & Japan: Hokkaido, Sapporo-shi, Mt. Muine, 06.07.1982, Takahashi 2687 (SAPS) \\
\hline
\end{tabular}


Pollen grains were acetolysed following Sarwar and Takahashi (2012a). For LM, the dehydrated (in an ethanol series) pollen was mounted in silicone oil (viscosity $3000 \mathrm{cs}$ ), and examined and measured with a Nikon Eclipse E200 microscope. The dimensions "D", "P", "d(E)" and " $2 \mathrm{f}$ ", corresponding to the tetrad diameter, polar length, equatorial length and colpus length of pollen grain were measured, and the D/d, P/E and 2f/D ratio was calculated (Oldfield, 1959). The arithmetic mean, standard deviation and the maximum and minimum values were calculated using the XLSTAT 2009.3 program. Pollen slides of all collections are deposited at the Hokkaido University Museum, Sapporo, Japan. Pollen size and shape classes were used following Erdtman (1986) and descriptive terminology follows Sarwar et al. (2006) and Punt et al. (2007).

For SEM, the acetolysed pollen samples were dehydrated in an ethanol series, mounted and air dried on aluminum stubs from $70 \%$ ethanol, and sputter coated with Platinum-Palladium using a Hitachi E102 ion sputter. Subsequently, these were examined and photographed with a Jeol JSM-5310 LV scanning electron microscope operated at $15 \mathrm{KV}$. The SEM micrographs of apocolpial exine sculpture from similar positions were used for the purpose of description and comparison.

For TEM, material from herbarium specimens was rehydrated in 3\% Aerosol-OT solution for more than one week, and then fixed overnight in $1 \%$ osmium tetraoxide solution. Fixed materials were dehydrated through an ethanol series and embedded in Epon 812 epoxy resin. Sections were cut using a Reichert-Jung Ultracut $\mathrm{N}$ ultratome, and post-stained with saturated uranyl acetate and lead acetate solution for $23 \mathrm{~min}$ ( $20 \mathrm{~min}$ and $3 \mathrm{~min}$, respectively), and observed and photographed using a Hitachi H-800 transmission electron microscope operated at $75 \mathrm{KV}$.

\section{Results}

Pollen morphology of Rhododendron:

Pollen grains are in tetrahedral tetrads, rarely compact or lobed, grains somewhat shrunk in some species (severly in $R$. groenlandicum), rarely with other configurations, sometimes in giant dyads in R. tsusiophyllum; viscin threads present; D 30.9-67.1 $\mu \mathrm{m}, \mathrm{P} 16.3-35.8 \mu \mathrm{m}, \mathrm{E} 21.8-47.5$ $\mu \mathrm{m}, \mathrm{D} / \mathrm{d}$ 1.31-1.51, P/E 0.66-0.81, oblate or suboblate; 3-colporate, rarely 4-colporate in $R$. kaempferi, finely demarcated, 2f 14.5-30.4 $\mu \mathrm{m}$, W 0.7-2.2 $\mu \mathrm{m}, 2 \mathrm{f} / \mathrm{W}$ 6.59-35.43, 2f/D 0.31-0.54, costae present, distinct or indistinct, colpus margin distinct; endocracks present; endoaperture lalongate, 0.6-2.6 $\mu \mathrm{m}$ long, 6.8-15.2 $\mu \mathrm{m}$ wide; apocolpial exine 1.7-3.6 $\mu \mathrm{m}$ thick, septum 0.6-3.6 $\mu \mathrm{m}$ thick; tectate, apocolpial exine sculpture from verrucate to rugulate (Table 2). In SEM, the pollen surface varies from uneven and rugged to flat, primary apocolpial exine sculpture indistinct, secondary sculpture finely $(0.1-0.25 \mu \mathrm{m})$ to moderate $(0.25-0.4 \mu \mathrm{m})$ gemmate-pilate (Type GP; Figs. 1F, G, I-O, 2A-D, G-O, 3A-E); or surface rugged to flat, apocolpial exine sculpture coarsely rugulate, grooves distinct (Type R; Figs 2E, F, 3F); or intermediate (Fig. 1H); colpus membrane granulate to granuloid or rarely smooth.

Three species of Rhododendron, viz. $R$. japonicum, $R$. schlippenbachii and $R$. tsusiophyllum were studied with TEM. The apocolpial exine is composed of ektexine and endexine (Figs 4A - I). Sexine is c. 1.1-1.3 $\mu \mathrm{m}$ thick, tectum canalized in R. japonicum (Fig. 4E), and a total exine is c. $1.8-2.1 \mu \mathrm{m}$ thick. The septum is c. $0.9-1.9 \mu \mathrm{m}$ thick. The intine is almost evenly thick around the pollen tetrad, showing lower electron density than the endexine beneath both the apocolpial and septal exine.

\section{Pollen morphology of Therorhodion:}

Pollen of $T$. redowskianum was studied only with SEM. Pollen grains are in lobed tetrahedral tetrads; viscin threads present; D $50.0 \mu \mathrm{m}$, P $26.5 \mu \mathrm{m}$, E $35.0 \mu \mathrm{m}, \mathrm{D} / \mathrm{d} 1.43, \mathrm{P} / \mathrm{E}$ 0.76, suboblate; 


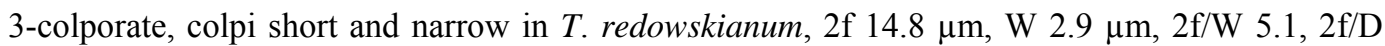
0.3 , costae present and distinct, colpus margin distinct; endocracks present; endoaperture lalongate, $1.7 \mu \mathrm{m}$ long, $9.7 \mu \mathrm{m}$ wide; apocolpial exine $2.2 \mu \mathrm{m}$ thick, septum $1.4 \mu \mathrm{m}$ thick; tectate, apocolpial exine sculpture from verrucate to rugulate (Table 2).
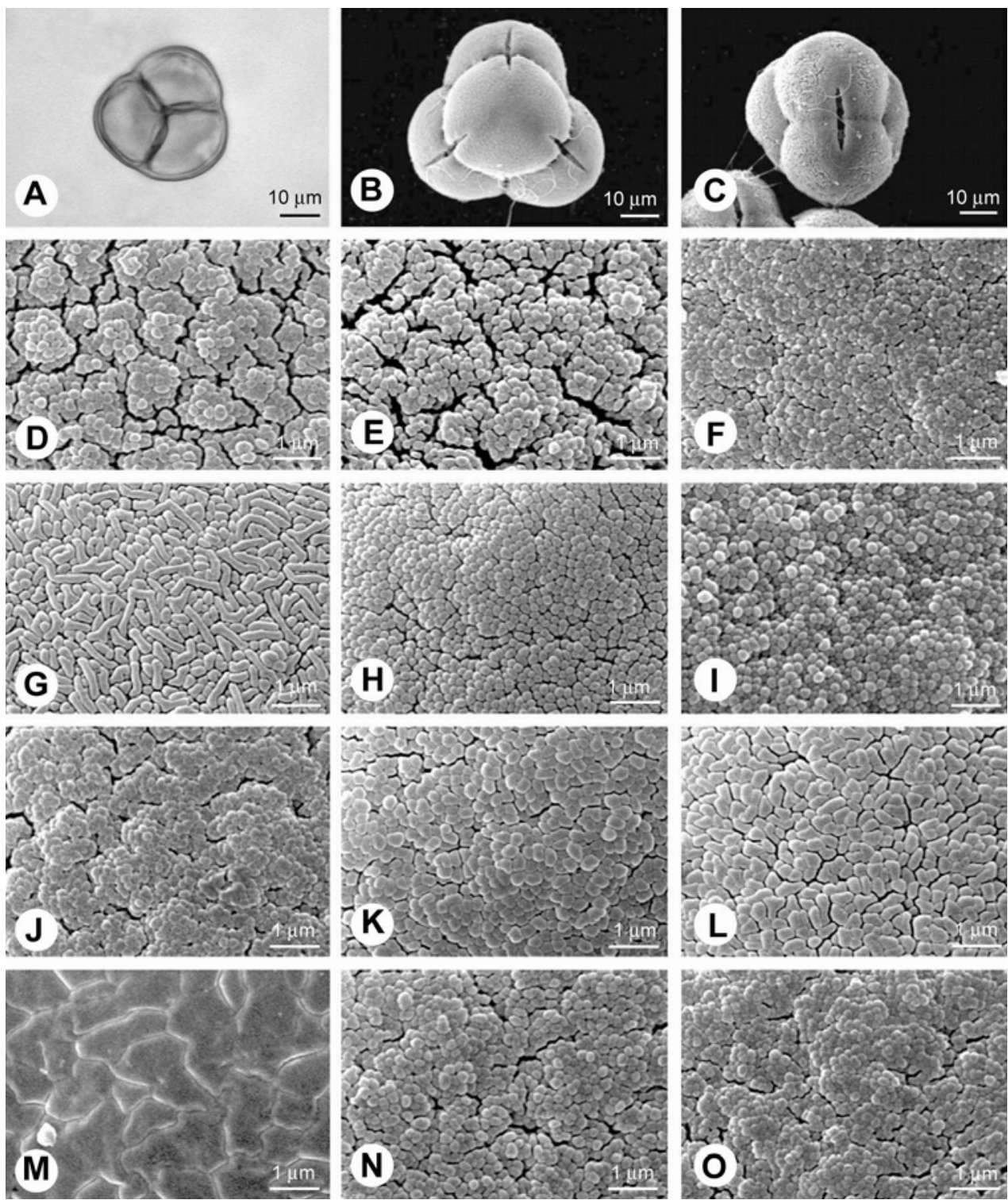

Fig. 1. LM and SEM micrographs of Rhododendron pollen. A) R. formosanum (Murata 17561); B) R. maddeni (Kanai et al. 346?). C) R. tsusiophyllum (Sawada s.n.); D) R. aureum (Takahashi 2512); E) R. kaempferi (Iketsu et al. 95); F) $R$. aureum (Takahashi 2512); G) R. brachycarpum (Takahashi et al. 40); H) R. decorum (Smith 2016); I) $R$. degronianum (Iketani 1763); J) R. formosanum (Murata 17561); K) R. macrostemon (Togasi 688); L) R. viscistylum var. amakusaense (Minamidani 29613); M) R. semibarbatum (Murata 7987); N) R. arborescens (Unknown s.n.); O) R. albrechtii (Takahashi 3975). Pollen tetrads at polar view (A-D); tetrads with viscin threads (A, B, D); pollen tetrad at equatorial view with viscin threads (E); micrographs with apocolpial exine sculpture details (F-O). 
In SEM, pollen surface is uneven and rugged, primary apocolpial exine sculpture indistinct, secondary sculpture finely $(0.1-0.25 \mu \mathrm{m})$ to moderate $(0.25-0.4 \mu \mathrm{m})$ gemmate-pilate (Type GP; Figs 5D-E); colpus membrane granuloid or smooth.
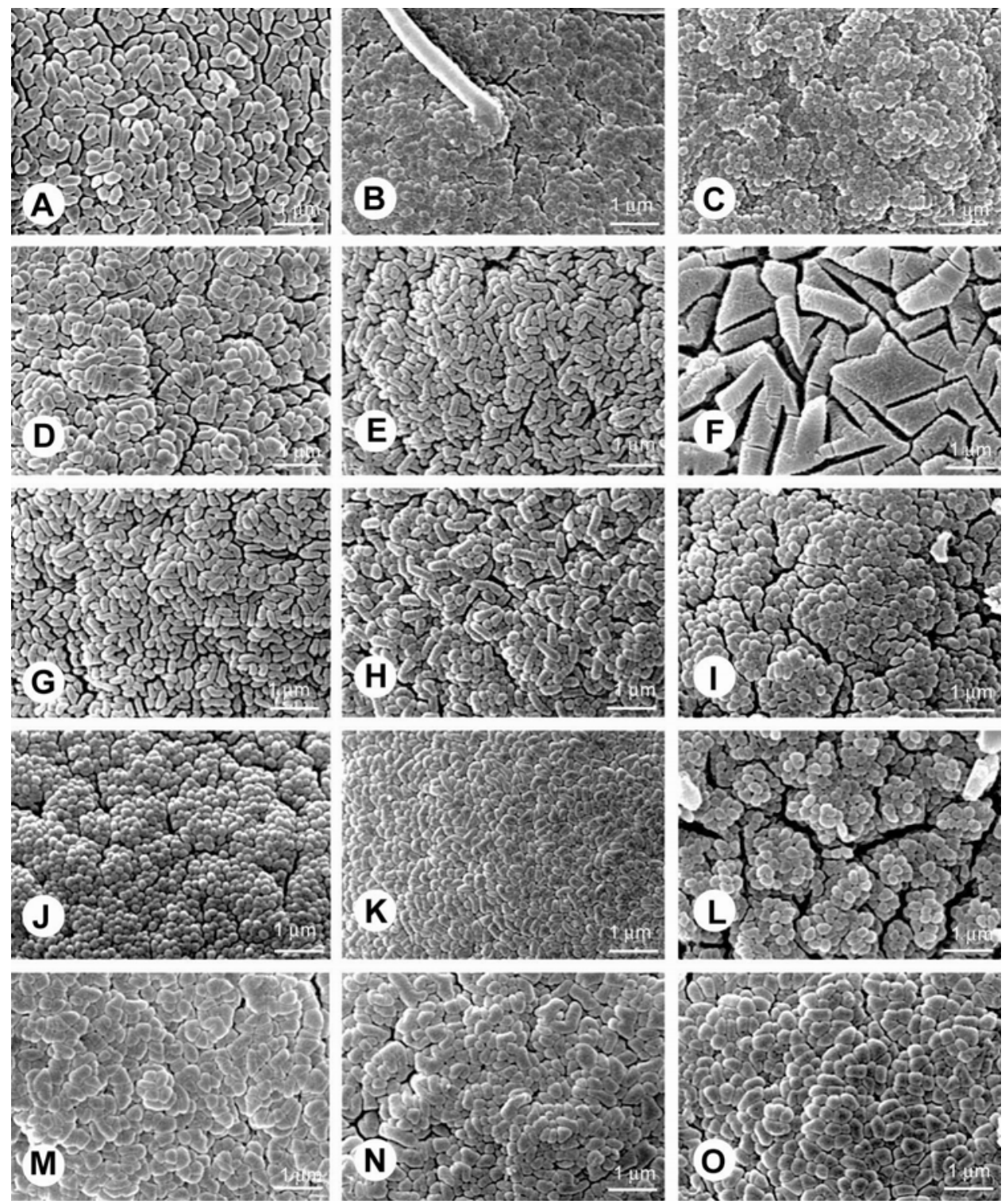

Fig. 2. SEM micrographs of Rhododendron pollen. A) R. quinquefolium (Ogura 1637); B) R. schlippenbachii (Sarwar \& Takahashi s.n.); C) R. lapponicum (Gillett 1835); D) R. parvifolium (Tatewaki 20940); E) R. diversipilosum (Takahashi 206); F) $R$. subarcticum (Takahashi 2643); G) $R$. dauricum (Kanayama et al. 04-9050); H) $R$. mucronulatum var. ciliatum (Yokoyama 299); I) R. davidsoniaum (C. 9180); J) R. keiskei (Murata et al. 17861); K) R. dilatatum (Togashi s.n.); L) R. hidakanum (Tateishi \& Togashi s.n.); M) R. wadanum (Takahashi 550); N) $R$. weyrichii (Shimamura et al. s.n.); O) R. indicum (Miyabe s.n.). Micrographs with apocolpial exine sculpture details (A-O); base of viscin threads attached with apocolpial exine (tectum) (A). 


\section{Pollen morphology of Menziesia:}

Pollen of M. cilicalyx and M. goyozanensis was studied only with SEM. Pollen grains are in tetrahedral tetrads, lobed or compact; viscin threads commonly absent except in M. pentandra; D 34.3-36.7 $\mu \mathrm{m}, \mathrm{P} 17.4-18.7 \mu \mathrm{m}, \mathrm{E} 24.0-27.5 \mu \mathrm{m}, \mathrm{D} / \mathrm{d} 1.33-1.43$, P/E 0.68-0.73, oblate; 3-colporate, 2f 15.4-17.6 $\mu \mathrm{m}, \mathrm{W} 1.1-1.7 \mu \mathrm{m}, 2 \mathrm{f} / \mathrm{W}$ 9.06-16.0, 2f/D 0.42-0.51, costae present and distinct, colpus margin distinct; endocracks present; endoaperture lalongate, 1.0-1.8 $\mu \mathrm{m}$ long, 6.2-8.7 $\mu \mathrm{m}$ wide; apocolpial exine $1.7 \mu \mathrm{m}$ thick, septum 1.0-1.2 $\mu \mathrm{m}$ thick, with faint perforations in $M$. pentandra; tectate, apocolpial exine sculpture finely verrucate (Table 2).
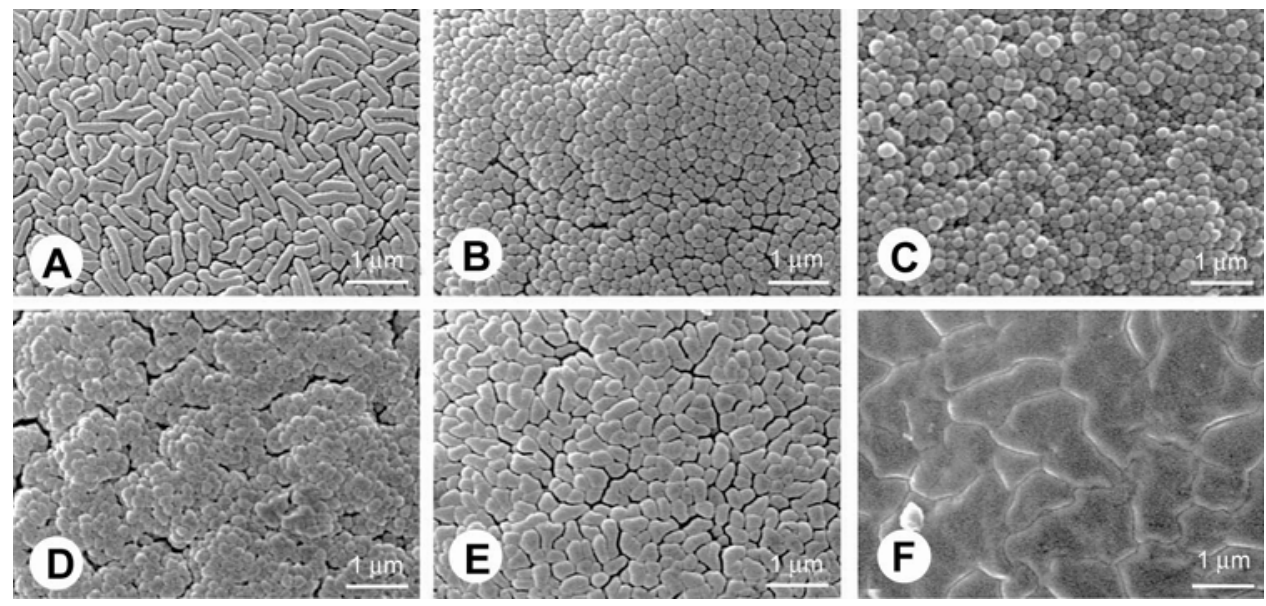

Fig. 3. SEM micrographs of Rhododendron pollen. A) R. japonicum (Takahashi 3998); B) R. kaempferi (Iketsu et al. 95);

C) R. macrosepalum (Takahashi 1033); D) R. nudipes (Murata 10910); E) R. trinerve (Togashi s.n.); F) $R$. tsusiophyllum (Sawada s.n.). Micrographs with apocolpial exine sculpture details (A-F).

In SEM, pollen surface is flat, primary apocolpial exine sculpture indistinct, secondary sculpture unit narrowly straight-edged striate (Type NS; Figs 5I, K); or coarsely rugulate, lirae striate (Type R; Fig. 5L); colpus membrane granuloid to smooth.

In TEM of M. pentandra, the apocolpial exine is composed of ektexine and endexine (Figs. $5 \mathrm{M}-\mathrm{O}$ ). Sexine is c. $1.0 \mu \mathrm{m}$ thick, and the total exine is c. $1.9 \mu \mathrm{m}$ thick (Fig. $5 \mathrm{~N}$ ). The septum is c. 1.3-1.9 $\mu \mathrm{m}$ thick. The intine is almost evenly thick around the pollen tetrad, showing lower electron density than the endexine beneath both the apocolpial and septal exine.

\section{Discussion}

The genus Rhododendron is stenopolynous, having 3-colporate and medium pollen tetrads with viscin threads. A continuous and serial variation was revealed in all quantitative palynological characters within the genus (Tables $2 \& 3$ ). The size of Rhododendron pollen tetrads varies widely between $30.9 \mu \mathrm{m}$ and $67.1 \mu \mathrm{m}$ (Table 2).

No distinct difference in tetrad size was observed among the subfamilies, however, the subgenera Hymenanthes and Pentanthera produced relatively larger $(48 \mu \mathrm{m})$ pollen tetrads (Table 3). Variations in ploidy level might be one of the probable causes of this wide variation in pollen size among Rhododendron species. In Rhododendron, enormous species diversification has 


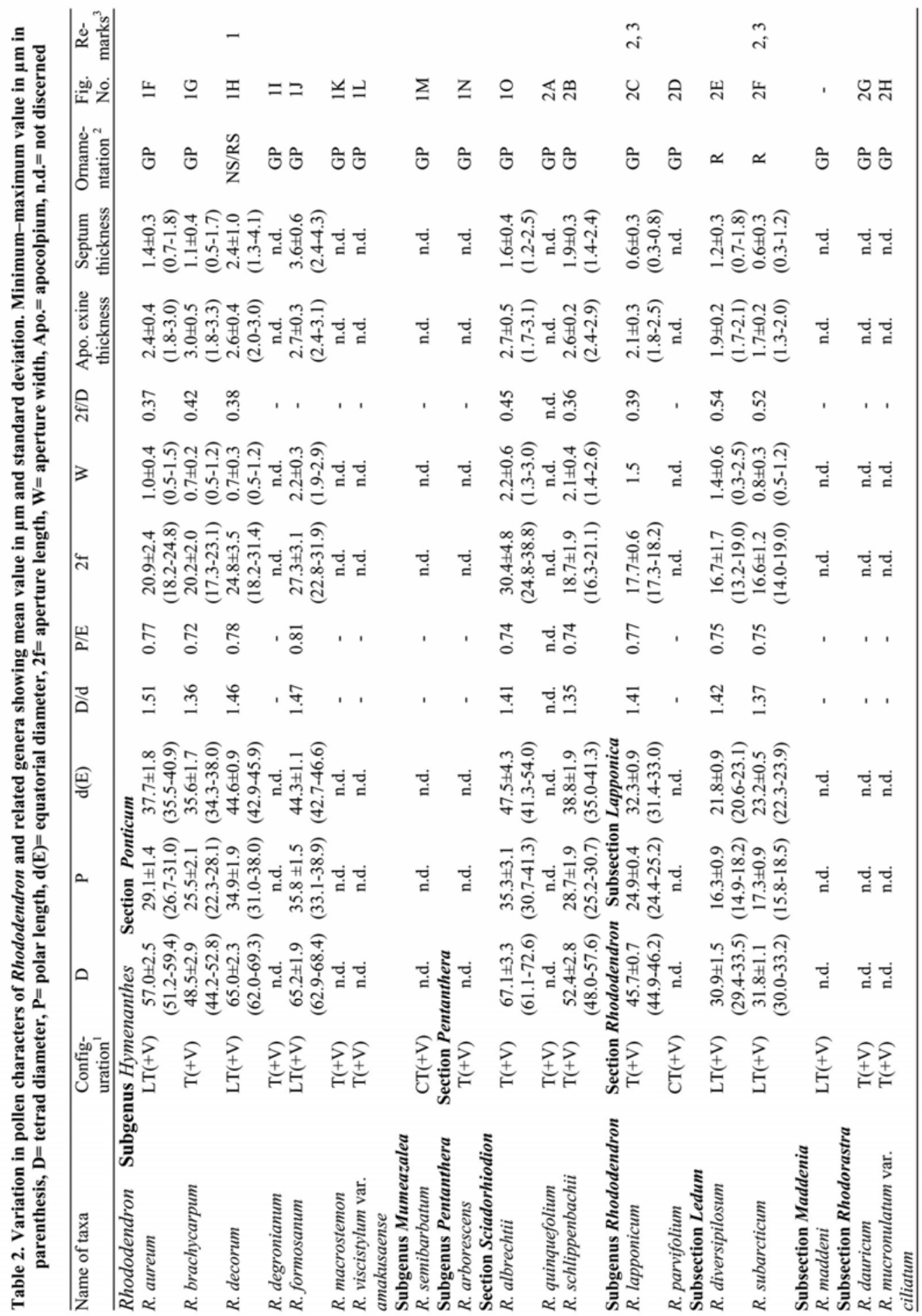




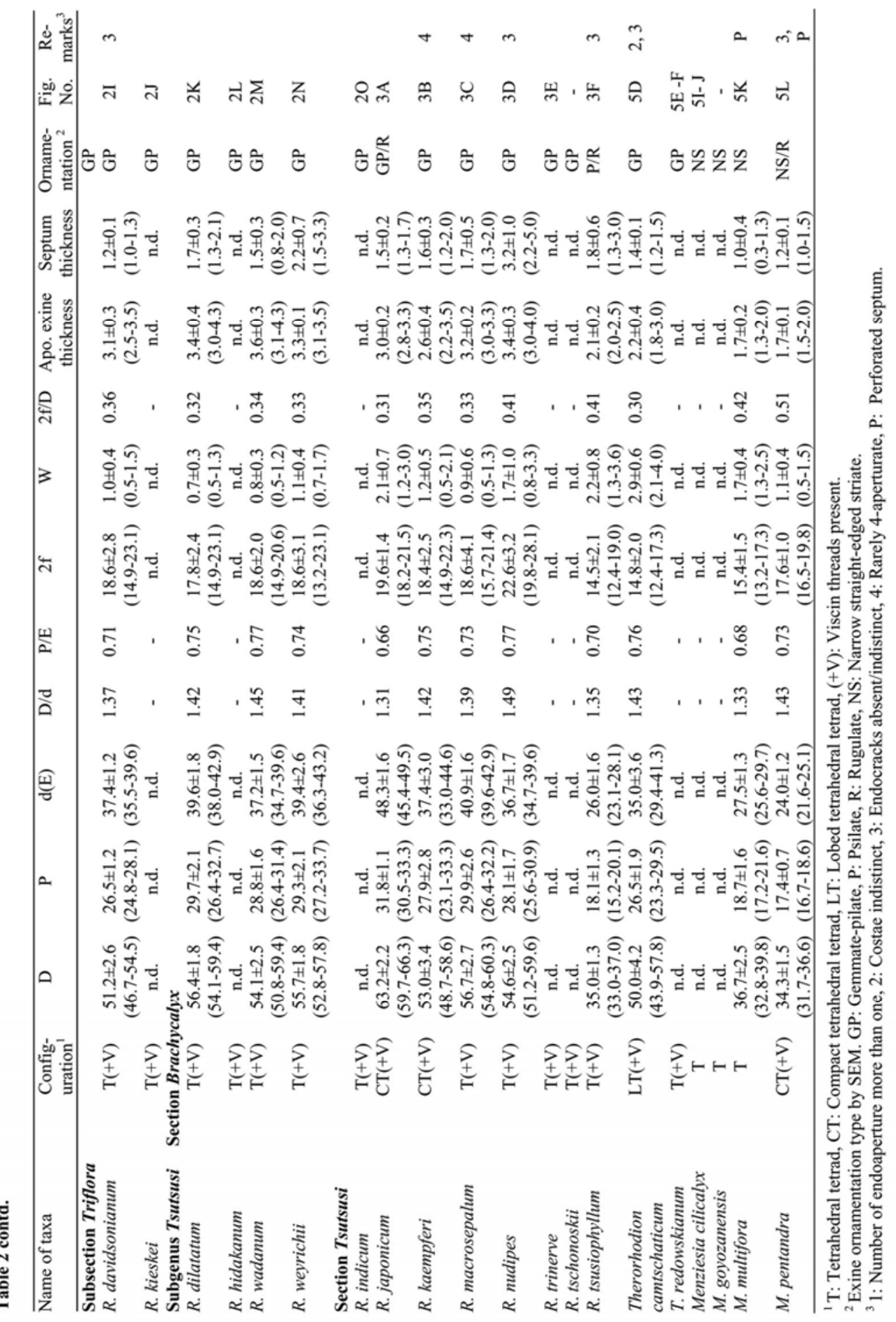




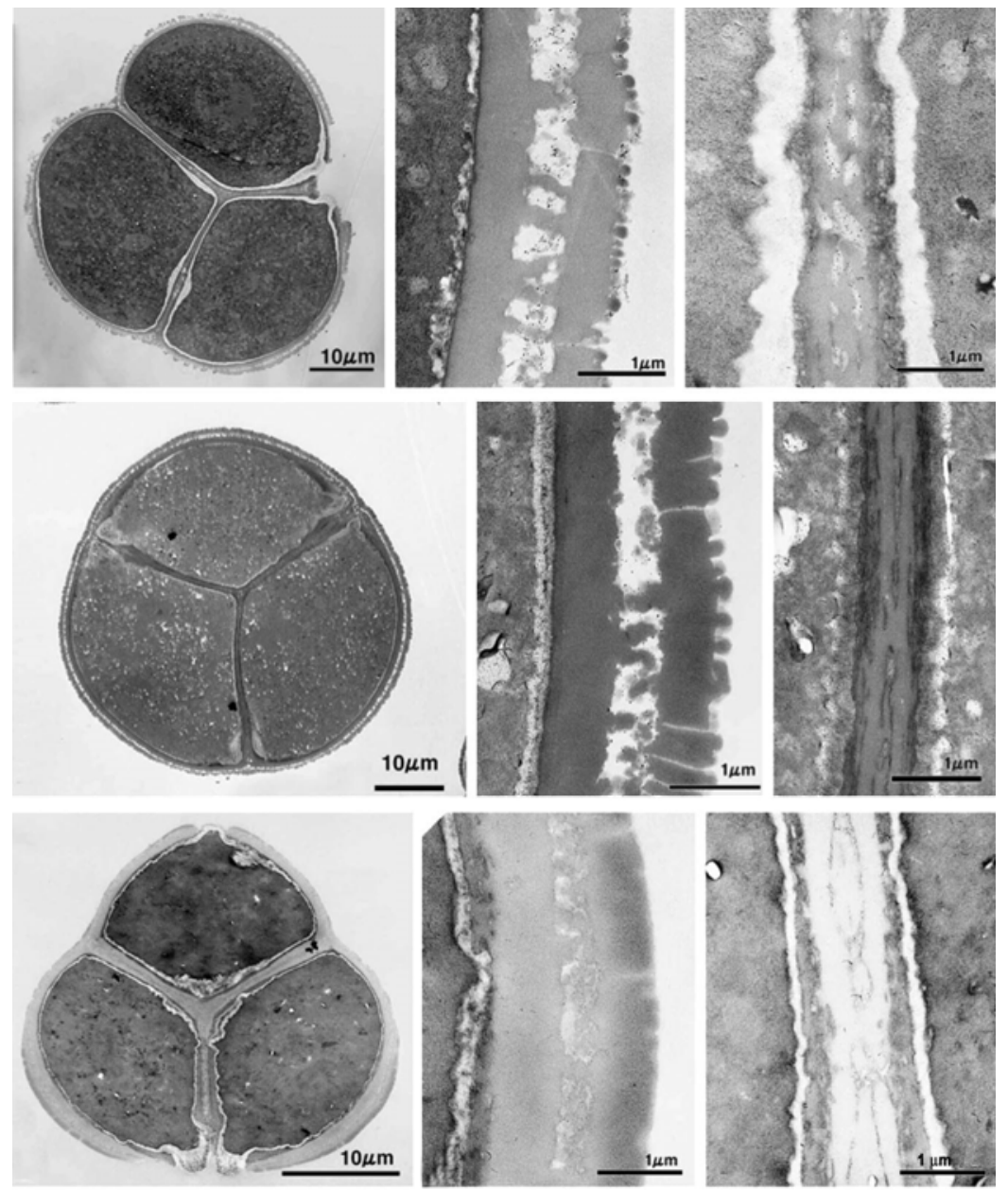

Fig. 4. TEM micrographs of Rhododendron pollen. A-C) Rhododendron schlippenbachii (Sarwar \& Takahashi s.n.); D-F) R. japonicum (Takahashi 3998); G-I) R. tsusiophyllum (Sawada s.n.). Whole tetrad (A, D, G); apocolpial exine showing thick canalized tectum with supratectal fine gemmae-pila, thick columellae, thick foot layer and thin endexine (B); in septum, tectum fragmentary, two foot layer of adjacent grains sometimes connected by columellae, endexine thick (C); apocolpial exine showing canalized thick tectum with supratectal fine gemmae-pila, thick columellae, thick foot layer and thin endexine (E); in septum, tectum lacking, two foot layer of adjacent grains connected by thin or rudimentary columellae, endexine thick (F, I); apocolpial exine showing thick tectum, columellae, thick foot layer and endexine with (endo) cracks $(\mathrm{H})$.

clearly occurred at the diploid level $(2 \mathrm{n}=26)$, and polyploidy occurs among one third of cytologically examined lepidote species, the degree of polyploidy ranging from triploids $(2 n=3 x=39)$ to dodecaploids $(2 n=12 x=156)$ (Janaki Ammal, 1950). Aneuploidy $(2 n=30)$ has been reported in one case (Jones and Brighton, 1972) and two species namely, R. wallichii Hook. f. (as $R$. campanulatum var. wallichii Hook. f.) and $R$. grande Wight were reported to have $\mathrm{n}=12$ (i.e. $2 \mathrm{n}=24$ ) (Mehra, 1976), although the number of Rhododendron species having diploid level $(2 \mathrm{n}=24)$ should be increased after the inclusion of Therorhodion (Kron and Judd, 1990). Cockerham and Galletta (1976) reported that the mean pollen diameter was 11\% larger in the tetraploids compared to that in the diploids in certain Vaccinium species. 
Viscin threads occur among the pollen tetrads in Rhododendron and Therorhodion, and presumably play a role in pollen removal from the anthers and its adhesion to pollinators. Any pollen material with viscin threads points to the highly specialized (entomophilous) pollination mode. It has been suggested that viscin threads increase the efficiency of pollination, and their presence implies highly specific pollinators for accurate delivery of pollen to stigma (Hesse et al., 2000). The viscin threads would also play a role in pollen presentation. According to Skvarla et al. (1978) there is significant association between the structure of viscin threads in Onagraceae and the pollen vector: beaded viscin threads associated with birds and moth pollinated taxa whereas smooth ones occur in bee pollinated taxa. No viscin threads were found in Menziesia (despite reports to the contrary in Copeland, 1943; Wood, 1961), except in M. pentandra (Table 2). Viscin threads are not to be expected in species with urceolate or tubular corollas, since there they might obstruct cross-pollination (Stevens, 1971). Thus they are found in M. pentandra, which has broadly urceolate (to campanulate) corollas, but not in other species of the genus with urceolate and/or tubular corollas.

Table 3. Variation in pollen characters of different subgenera of Rhododendron showing minimummaximum (mean) value in $\mu \mathrm{m}$. D: tetrad diameter, $2 \mathrm{f}$ : aperture length, $\mathrm{W}$ : aperture width.

\begin{tabular}{|c|c|c|c|c|c|}
\hline $\begin{array}{l}\text { Name of } \\
\text { subgenera }\end{array}$ & $\mathrm{D}$ & $2 \mathrm{f}$ & $\mathrm{W}$ & $\begin{array}{l}\text { Exine } \\
\text { sculpture }\end{array}$ & Reference \\
\hline Azaleastrum & $39.18-56.93$ & $8.89-23.92$ & $0.86-2.36$ & GP & Gao et al. (2002b) \\
\hline Candistrum & $37.97-39.95$ & 13.80 & $1.29-1.38$ & GP & Gao et al. (2002b) \\
\hline Hymenanthes & $48.50-65.20$ & $16.53-20.20$ & $0.70-2.90$ & GP, R & This paper; Gao et al. (2002c) \\
\hline Mumeazalea & $35.85-39.95$ & 16.10 & $1.85-1.98$ & GP & Gao et al. (2002b) \\
\hline Pentanthera & $49.04-67.10$ & $18.70-30.40$ & $1.56-3.44$ & GP & $\begin{array}{l}\text { This paper; Gao et al. (2002c); } \\
\text { Zhang et al. (2009) }\end{array}$ \\
\hline Rhododendron & $30.29-54.84$ & $9.63-20.23$ & $0.80-1.50$ & GP, R & This paper; Gao et al. (2002c) \\
\hline Tsutsusi & $35.00-63.20$ & $13.97-22.60$ & $0.70-2.20$ & GP, R & $\begin{array}{l}\text { This paper; Gao et al. (2002c); } \\
\text { Zhang et al. (2009) }\end{array}$ \\
\hline
\end{tabular}

Usually, apocolpial exine is thicker than the septal exine, but thinner apocolpial exine has been observed in $R$. formosanum (Table 2). Similar relatively thinner apocolpial exine also has been observed in some taxa of the subfamily Vaccinioideae (Sarwar and Takahashi, 2006; Sarwar et al., 2006) and it may have some taxonomic value in the infrageneric classification of the respected genera. In the lobed tetrads of $R$. formosanum, single pollen grains might be loosely attached together and the septum has not been reduced. A similar cause for comparatively thicker septum has been discussed for tetrads of the family Annonaceae (Le Thomas et al., 1986). However, no significant correlation was found between compactness of tetrad and septum thickness in the present study or published literature (Kim et al., 1988).

The apocolpial exine sculpture can be divided into two distinct groups - pollen surface is uneven and rugged to somewhat flat, apocolpial exine sculpture of Type GP (Figs 1F, G, I-O, 2AD, G-O, 3A-E); and pollen surface flat or rugged, apocolpial exine sculpture of Type R (Figs 2E, F, 3F). The latter type of exine sculpture characterized Rhododendron subsect. Ledum, and all other species have almost similar exine sculpture except $R$. tsusiophyllum (Fig. 3F). The subsect. Ledum was also characterized by smaller pollen tetrads $(30.9-31.8 \mu \mathrm{m})$ and a higher value of $2 \mathrm{f} / \mathrm{D}$ ratio (0.52-0.54) (Table 2). Neither tetrad size nor exine sculpture was able to be used to differentiate among the subgenera and/or sections of Rhododendron (Tables 2, 3). Thus, palynological characters showed little usefulness in the infrageneric classification of 
Rhododendron (Goetsch et al., 2005), but could be used for identification of individual Rhododendron species (Table 2; Gao et al., 2002b, c).

Generic delimitation of the tribe Rhodoreae is a subject of dispute until now (Gillespie and Kron, 2010). The phylogenetic analyses of Rhododendron based on molecular data did not support the individual generic status of Menziesia and Therorhodion, or even Diplarche (Craven, 2011), but suggested their inclusion within the genus Rhododendron (Kurashige et al., 2001; Goetsch et al., 2005). The results of this palynological study added some new points of disagreement within the present generic alignment of this tribe (Gillespie and Kron, 2010). As expected, the quantitative palynological features vary to a large extent in a large genus like Rhododendron, and give a little support for the individual generic status of Menziesia, Rhododendron and Therorhodion (Table 2). However, the specialized exine sculpture of Type NS and perforated septum of Menziesia, clearly distinguish the genus from other two genera of this tribe, Rhododendron and Therorhodion (Table 2; Figs 1-3, 5; Gao et al., 2002c; Miyoshi et al., 2011). Both the exine sculpture and septum with perforations have already been identified as taxonomically important characters in different Ericaceous genera (Sarwar, 2007). Along with other morphological and molecular characters (Kron et al., 2002; Gillespie and Kron, 2010), the exceptional exine sculpture may also give additional support to the individual generic status of Menziesia (Sarwar and Takahashi, 2012b; Takahashi and Sarwar, 2013). Palynological features of the other two genera, Rhododendron and Therorhodion are very similar (Table 2; Figs 1-3, 5), and they might support the sister relationship between these two genera as identified by Gillespie and Kron (2010).

The pollen morphological features e.g., tetrad size, exine sculpture, etc. of $R$. tsusiophyllum of sect. Tsutsusi are different from those of other members of the same section as well as subgen. Tsutsusi (Table 2; Type GP; Figs 2K-O, 3A-E vs. Type R; Fig. 3F). Taking pollen morphology into account $R$. tsusiophyllum might be transferred from the subgen. Tsutsusi (Chamberlain et al., 1996) to subsect. Ledum of the subgen. Rhododendron (Table 2; Type R; Figs 2E, F). Similar transfer of $R$. huadingense from sect. Brachycalyx of the subgen. Tsutsusi to subgen. Pentanthera has also been proposed based on palynological features (Zhang et al., 2009). In TEM, the pollen wall structure of $R$. tsusiophyllum especially the thickness of the columellae and the sexine-nexine ratio also showed a distinct difference (data not shown) compared to the two other taxa of Rhododendron (Fig. 4). When considering the differences in the breakdown of the separating wall of the pollen sac, opening of the anther during maturity and the three-locular ovary as well as differences in other morphological characters between $R$. tsusiophyllum and other Rhododendron species (Stevens, 1969; Yamazaki, 1991); R. tsusiophyllum might be recognized as a separate monotypic genus Tsusiophyllum; T. tanakae Maxim., which is sister to whole of Rhododendron (including Ledum) (Kron and Judd, 1990). The recent molecular phylogenetic study of subfamily Ericoideae (Gillespie and Kron, 2010) may also support this supposition. Rhododendron tsusiophyllum forms a clade with Menziesia pilosa, which is well-supported in Bayesian and Maximum Likelihood analyses, instead of other Rhododendron species (Figs 1, 3 in Gillespie and Kron, 2010).

Based solely on molecular data, the classification and evolutionary relationship between plants is not always completely reliable (Stace, 2005), especially in genera like Rhododendron where polyploid species are a common phenomenon (Janaki Ammal, 1950). Hörandl (2006) also suggested that clades retrieved by phylogenetic analyses should not be used solely as a basis for classification, but should be regarded primarily as information for a better understanding of relationships. So, detailed phylogenetic analyses, using morphological, palynological and molecular data with larger number of specimens, are necessary to clarify generic circumscription of Rhododendron and its relationship with other closely related genera. 

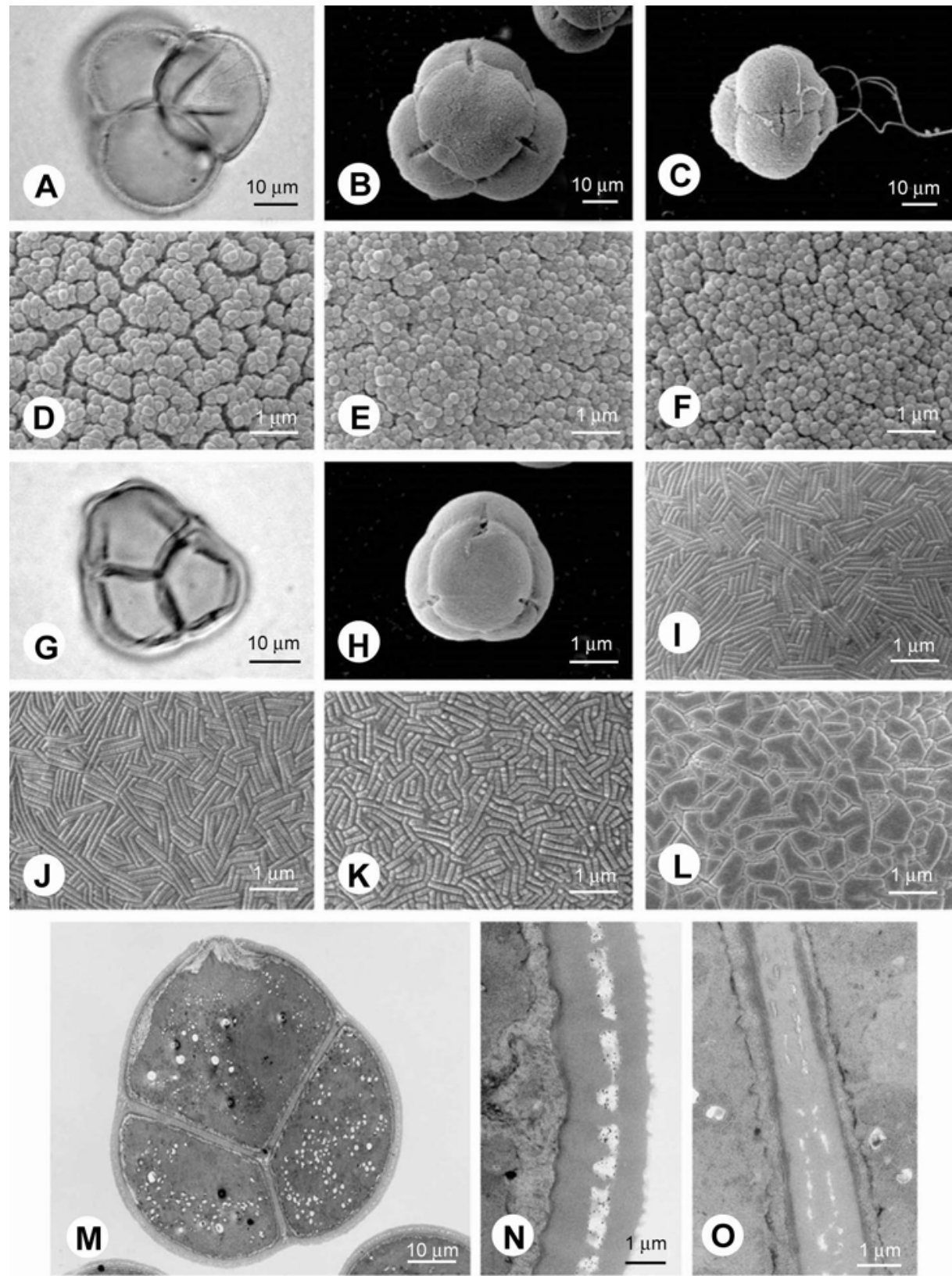

Fig. 5. LM, SEM and TEM pollen micrographs of Therorhodion (A-F) and Menziesia (G-O). A, B) Therorhodion camtschaticum (Takahashi et al. 5836); C) T. redowskianum (Yoshimura \& Hara s.n.); D) T. camtschaticum (Takahashi et al. 5836); E, F) T. redowskianum (Yoshimura \& Hara s.n.). G) Menziesia pentandra (Takahashi 2687); H) M. multiflora (Takahashi 767); I, J) M. cilicalyx (Tateishi \& Hoshi 13689); K) M. multiflora (Takahashi 767); L) M. pentandra (Takahashi 2687); M-O) M. pentandra (Takahashi 2687). Pollen tetrads at polar view (A, B, G, H); pollen tetrads at equatorial view showing aperturate $(\mathrm{C})$; micrographs with apocolpial exine sculpture details (D, E, I, $\mathrm{K}, \mathrm{L}$ ); micrograph with mesocolpial exine sculpture details (F, J); whole tetrad (M); apocolpial exine showing tectum with narrow straight-edged striae, columellae, foot layer and thin undulated endexine $(\mathrm{N})$; septum with tectum, and well defined columellae and foot layer of two adjacent grains $(\mathrm{O})$. 


\section{Acknowledgments}

The authors thank the Directors and Curators of the herbaria C, GB, SAPS, SAPT and TUS for allowing them to examine and/or send the specimens on loan and sample polliniferous materials. The first author is thankful to MEXT (Japanese Ministry of Education, Culture, Sports, Science and Technology) Scholarship during the period of this study.

\section{References}

Chamberlain, D.F., Hyam, R., Argent, G., Fairweather, G. and Walter, K.S. 1996. The genus Rhododendron - its classification and synonymy. Roy. Bot. Gard. Edinburgh, UK, 192 pp.

Cockerham, L.A. and Galletta, G.J. 1976. A survey of pollen characteristics in certain Vaccinium species. J. Amer. Soc. Hort. Sci. 101: 671-676.

Copland, H.F. 1943. A study, anatomical and taxonomic, of the genera of the Rhododendroideae. Am. Midl. Nat. 30: 533-625.

Craven, L.A. 2011. Diplarche and Menziesia transferred to Rhododendron. Blumea 56: 33-35.

Erdtman, G. 1986. Pollen Morphology and Plant Taxonomy - Angiosperms. E. J. Brill, Leiden. 553 pp.

Fuhsiung, W., Nanfen, C., Yulong, Z. and Huiqiu, Y. 1995. Pollen Flora of China. 2nd ed. Institute of Botany, Academia Sinica. 461 pp. +205 plates (in Chinese).

Gao, L-M., Li, D-Z., Zhang, C-Q. and Yang, J-B. 2002a. Infrageneric and sectional relationships in the genus Rhododendron (Ericaceae) inferred from ITS sequence data. Acta Bot. Sin. 44: 1351-1356.

Gao, L-M., Zhang, C-Q., Li, D-Z. and Wei, Z-X. 2002b. Pollen morphology of Rhododendron subgenus Azaleastrum. J. Wuhan Bot. Res. 20: 177-181 (in Chinese with English abstract).

Gao, L-M., Zhang, C-Q., Li, D-Z. and Wei, Z-X. 2002c. Pollen morphology of Rhodoreae (Ericaceae) and its systematic implication. Acta Bot. Yunn. 24: 471-482 (in Chinese with English abstract).

Gillespie, E. and Kron, K.A. 2010. Molecular phylogenetic relationships and a revised classification of the subfamily Ericoideae (Ericaceae). Mol. Phylogen. Evol. 56: 343-354.

Goetsch, L., Eckert, A.J. and Hall, B.D. 2005. The molecular systematics of Rhododendron (Ericaceae): A phylogeny based on RPB2 gene sequences. Syst. Bot. 30: 616-626.

Hesse, M., Vogel, S. and Halbritter, H. 2000. Thread-forming structures in angiosperm anthers: their diverse role in pollination ecology. Plant Syst. Evol. 222: 281-292.

Holmgren, P.K., Holmgren, N.H., and Barnett, L.C. (Eds). 1990. Index Herbariorum, Part I: The Herbaria of the World. $8^{\text {th }}$ ed. New York Bot. Gard., Bronx. 704 pp.

Hörandl, E. 2006. Paraphyletic versus monophyletic taxa - evolutionary versus cladistic classification. Taxon 55: $564-570$.

Huang, T.C. 1972. Pollen Flora of Taiwan. National Taiwan University, Bot. Dept. Press. 297 pp.

Janaki Ammal, E.K. 1950. Polyploidy in the genus Rhododendron. The Rhododendron Yearbook 5: 92-96.

Jones, K. and Brighton, C. 1972. Chromosome numbers of tropical Rhododendrons. Kew Bull. 26: 559-561.

Kim, K.H., Nilsson, S. and Praglowski, J. 1988. A note on the pollen morphology of the Empetraceae. Grana 27: 283-290.

Kron, K.A. and Judd, W.S. 1990. Phylogenetic relationships within the Rhodoreae (Ericaceae) with specific comments on the placement of Ledum. Syst. Bot. 15: 57-68.

Kron, K.A., Judd, W.S., Stevens, P.F., Crayn, D.M., Anderberg, A.A., Gadek, P.A., Quinn, C.J. and Luteyn, J.L. 2002. Phylogenetic classification of Ericaceae: molecular and morphological evidence. Bot. Rev. 68: $335-423$.

Kurashige, Y., Etoh, J.I., Handa, T., Takayanagi, K. and Yukawa, T. 2001. Sectional relationships in the genus Rhododendron (Ericaceae): evidence from matK and trnK intron sequences. Plant Syst. Evol. 228: $1-14$. 
Le Thomas, A., Morawetz, W. and Waha, M. 1986. Pollen of palaeo- and neotropical Annonaceae: definition of the aperture by morphological and functional characters. In Blackmore, S. and Ferguson, I.K. (Eds), Pollen and Spores: Form and Function, Academic Press, London. pp. 375-388.

Linnaeus, C. 1753. Species Plantarum. Stockholm.

Mao, Z-J., Yang, Y-F. and Hou, L-J. 2000. A study on pollen morphology of Rhododendron in northeast of China. Bull. Bot. Res. (Harbin). 20: 58-62 (in Chinese with English abstract).

Mehra, P.N. 1976. Cytology of Himalayan Hardwoods. Sree Sarawaty Press, Calcutta, 235 pp.

Miyoshi, N., Fujiki, T. and Kimura, H. 2011. Pollen Flora of Japan. Hokkaido Univ. Press, Sapporo. (in Japanese).

Oldfield, F. 1959. The pollen morphology of some of the West European Ericales - Preliminary descriptions and a tentative key to their identification. Pollen et Spores 1: 19-48.

Punt, W., Hoen, P.P., Blackmore, S., Nilsson, S. and Le Thomas, A. 2007. Glossary of pollen and spore terminology. Rev. Palaeob. Palynol. 143: 1-81.

Sarwar, A.K.M. Golam. 2007. Pollen morphology and its systematic significance in the Ericaceae. PhD Thesis., Graduate School of Agriculture, Hokkaido Univ., Japan (unpublished), 302 pp.

Sarwar, A.K.M. Golam and Takahashi, H. 2006. The taxonomic significance of pollen morphology in Andromedeae s.s., Gaultherieae, Lyonieae and Oxydendreae (Ericaceae: Vaccinioideae). Jpn. J. Palynol. 52: 77-96.

Sarwar, A.K.M. Golam and Takahashi, H. 2012a. Pollen morphology of Kalmia (Phyllodoceae, Ericaceae) and its taxonomic significance. Bangladesh J. Plant Taxon. 19: 123-133.

Sarwar, A.K.M. Golam and Takahashi, H. 2012b. Pollen morphology and tribal classification of the subfamily Ericoideae (Ericaceae). Jpn. J. Palynol. 58 (Spec. Issue Abs.: IPC/IOPC 2012): 204.

Sarwar, A.K.M. Golam, Ito, T. and Takahashi, H. 2006. An overview of pollen morphology and its relevance to the sectional classification of Vaccinium L. (Ericaceae). Jpn. J. Palynol. 52: 15-34.

Skvarla, J.J., Raven, P.H., Chissoe, W.F. and Sharp, M. 1978. An ultrastructural study of viscin threads of Onagraceae pollen. Pollen et Spores 20: 5-143.

Sleumer, H. 1966. An account of Rhododendron in Malesia. Flora Malesiana. Ser. I, 6: 674-676.

Stace, C.A. 2005. Plant taxonomy and biosystematics - does DNA provide all the answers? Taxon 54: 9991007.

Stevens, P.F. 1969. Taxonomic studies in the Ericaceae. PhD Thesis., University of Edinburgh (unpublished). $678 \mathrm{pp}$.

Stevens, P.F. 1971. A classification of the Ericaceae: subfamilies and tribes. Bot. J. Linn. Soc. 64: 1-53.

Takahashi, H. and Sarwar, A.K.M. Golam. 2013. Pollen morphology and plant classification - An example of Menziesia (Ericaceae). Abs. $54^{\text {th }}$ Ann. Meet. Palynol. Soc. Japan. 32 p. (in Japanese)

Terzioğlu, S., Merev, N. and Anşin, R. 2001. A study on Turkish Rhododendron L. (Ericaceae). Turk. J. Agric. For. 25: 311-317.

Vasanthy, G. and Pocock, S.A.J. 1987. On the pollen tetrads of the south Indian Ericaceae, Gaultheria, Rhododendron and Vaccinium with special reference to R. nilagiricum Zenk. Bull. Jard. Bot. Nat. Belg. 57: 213-245.

Wang, Y-G., Li, G-Z., Qi, X-X. and Ou, Z-L. 2006. Pollen morphology of Rhododendron and its taxonomic implication. Guihaia 26: 113-119 (in Chinese with English abstract).

Wood, C.E.Jr. 1961. The genera of Ericaceae in the southeastern United States. J. Arnold Arb. 42: 10-80.

Yamazaki, T. 1991. Morphological structure of the anther of Tsusiophyllum tanakae Maxim. J. Jpn. Bot. 66: 35-38 (in Japanese with English summary).

Zhang, Y-J., Jin, X-F., Ding, B-Y. and Zhu, J-P. 2009. Pollen morphology of Rhododendron subgen. Tsutsusi and its systematic implication. J. Syst. Evol. 47: 123-138. 